\title{
Analis Pemilihan Umum Dalam Keadaan Masa Darurat Bencana Non Alam (Staatenoodrecht)
}

\author{
Izzul Islam ${ }^{1}$ \\ Universitas Trunojoyo Madura \\ Zurieque887@gmail.com
}

R. Wahjoe Poernomo Soeprapto ${ }^{2}$

Universitas Trunojoyo Madura

\begin{abstract}
ABSTRAK
Staatenoodrecht ialah hak darurat, dimana kegentingan kesehatan nasional sebagai ancama bagi masyarakat, maka dalam hal ini pemerintah tetap memaksakan Pemilihan Umum di tengah pandemi covid 19 yang melanda Indonesia dan ketegori darurat kesehatan nasional sudah tertuang di didalam kepres, Maka Pemilihan Umum yang dilaksanakan di tengah kondisi Negara dalam keadaan darurat harus di pertegas secara hukum yang berlaku, Jenis penetian ini Normatif, Adapun pendekatan yang digunakan adalah pendekatan perundang-undangan dan pendekatan konsep. Bahan hukum primer yang dianalisa adalah yang berhubungan keputusan presiden terhadap penetapan bencana dalam keadaan darurat, Bahan hukum sekunder di dapat dari literature terkait pelaksanaan pemilukada di tengah Negara dalam keadaan darurat.Hasil ini menunjukan bahwa ketika pilkada dilaksanakan di tengah keadaan darurat, maka kualitas hasil demokrasinya kurang baik, sejatinya jika keadaan neagara dalam darurat maka aktifitas yang membahayakan pada masyarakat harus di utamakan, dalam hal ini pemerintah masih belum konsisten terhadap penetapan covid 19 sebagai darurat kesehatan nasional, terbukti dengan terlaksananya pemilukada di tengah bencana non alam tersebut.
\end{abstract}

Kata Kunci: Darurat Kesehatan, Pemilihan Umum, Covid-19

\begin{abstract}
Staadnoodrecht is an emergency right, where the national health crisis is a threat to the community, so in this case the government continues to impose general elections in the midst of the covid 19 pandemic that hit Indonesia and the national health emergency category has been stated in the presidential decree. The state in a state of emergency must be confirmed by applicable law. This type of research is normative. The approach used is a statutory approach and a conceptual approach. The primary legal materials analyzed are those related to the presidential decree on the determination of disasters in an emergency, the secondary legal materials are obtained from literature related to the implementation of post-conflict local elections in the midst of a state of emergency. not good, actually if the state is in an emergency, activities that endanger the community must be prioritized, in this case the government is still not consistent with the determination of covid 19 as a national health emergency, as evidenced by the implementation of the post-conflict local election in the midst of these non-natural disasters.
\end{abstract}

Keywords: Health Emegergency, General Election, Covid-19 


\section{PENDAHULUAN}

Dalam keadaan darurat yang sudah termaktub dalam perundang-undangan ada beberapa kategori yang menjadikan pondasi untuk menentukan arah kebijakan dalam konteks kedaruratan nasional, dan hal yang berlaku Keadaan darurat memiliki arti yang luas, dapat berupa darurat militer atau darurat perang dan keadaan darurat akibat bencana alam, keadaan darurat administratif berupa keadaan darurat keuangan, atau keadaan darurat yang biasa disebut dengan keadaan darurat sosial.

Ketentuan-ketentuan tentang keadaan darurat tersebut direvisi dan di perbaiki berdasarkan Undang-Undang Dasar Negara Republik Indonesia Serikat Tahun 1949 (UUDRIS) dengan menggunakan istilah Urgensi dan Undang-Undang Darurat. Pasal 139, ayat (1), menyatakan: "Pemerintah berhak memberlakukan undang-undang darurat atas wewenang dan tanggung jawabnya sendiri untuk mengatur masalah administrasi federal yang harus segera diselesaikan karena keadaan mendesak." Ketentuan yang sama juga dimasukkan dalam Konstitusi tahun 1950 diadopsi. yaitu dalam "pasal 96 ayat (1)" yang berbunyi: "Pemerintah berhak atas kekuasaan dan tanggung jawabnya sendiri untuk menetapkan undang-undang darurat untuk mengatur urusan pemerintahan yang mendesak untuk diselesaikan".

Sedangkan dalam Undang-Undang Dasar Negara Republik Indonesia Tahun 1945, ketentuan tentang keadaan darurat diatur dalam dua pasal, yaitu "pasal 12 dan pasal
22". Keadaan bahaya ditentukan dengan hukum yang berlaku. Sedangkan pasal 22 mengatakan, "Dalam keadaan darurat yang mendesak, presiden berhak membuat peraturan negara, bukan undang-undang". 1

Sejak WHO menyatakan wabah penyakit Covid19 sebagai pandemi internasional, wabah penyakit Covid19 telah menyebar ke semua bidang kehidupan sosial, dari kesehatan masyarakat hingga ekonomi nasional, hingga akhirnya presiden memberikan status nasional sebagai darurat kesehatan nasional .

Berdasarkan definisi keadaan darurat dan kriteria tersebut di atas, maka pandemi Covid19 memenuhi semua kriteria tersebut, sehingga sebenarnya cukup jelas bahwa Indonesia saat ini dalam keadaan darurat. Hanya saja UUD NRI 1945 menyatakan bahwa penilaian negara dalam keadaan darurat atau tidak menjadi kewenangan khusus (prerogatif) Presiden. Kategori Covid-19 sudah merambah ke Indonesia, sehingga terjadilah beberapa konflik hukum, karena pada dasarnya konflik hukum tersebut harus menyesuaikan keadaan mengenai hukum tatanegara darurat, konlfik terkait pandemi Covid 19 juga mengakibtakan terjadinya penundaan pemilukaada, pro dan kontra pu terjadi, sehingga konflik mengenai bencana non alam tersebut, harus di pertimbangkan secara konsep peraturan hukum yang berlaku, karena kondisi ke daruratan kesehatan nasional, maka pemerintah harus berlandaskan

1 Jimly Asshiddiqie," Hukum Tata Negara Darurat"2007 R Raja Grafindo Persada, hal 205 
pada ketentuan kontitusi yaitu UUD NRI 1945 yang tertunag dalam pasl 12 tersebut. $^{2}$

Dalam kaitan kepastian hukum maka dengan asumsi dasar, pemilu di tengah bencana non alam secara teoritik seharusnya tidak terlaksana, kendati pun dalam hal aspek perundang-undangan yang berlaku, yang menjadi persoalan terhadap ketentuan mengenai pelaksanaan pemilu di tengah bencana non alam, hak preogratif yang menentukan kebijakan yaitu presiden, nah namun apakah pertimbangan presiden tersebut sudah memnuhi unsure-unsur hukum, kendatipun keadaan yang terjadi di masa pandemic covid 19 presiden sudah mengeluarkan Perppu Nomor 6 Tahun 2020 dan Kepres Nomor 12 Tahun 2020 Tentang Penetapan Bencana Non Alam Penyebaran Virus Corona Desease 2019.

Berdasarkan latar belakang masalah diatas dapat dirumuskan permasalahan sebagai berikut:

1. Apakah pandemi covid 19 di tahun 2020 termasuk kategori Negara dalam keadaan darurat staadnoodreht?

Bagaimanakah konsep ketentuan konstitusional Neagara dalam hal pemilu yang di jalankan dalam keadaan darurat?

\section{METODE PENELITIAN}

Metode penelitian yang digunakan hukum normatif, yaitu suatu proses untuk menemukan aturan hukum, prinsip-prinsip hukum, maupun

\footnotetext{
${ }^{2}$ Tomy Michael Tomy 163 Hukum Tata Negara Darurat Corona Di Indonesia volume 13 Nomor 2 Agustus 2020
}

doktrin-doktrin hukum guna menjawab isu hukum yang dihadapi. ${ }^{3}$ Ilmu Hukum berbeda dengan ilmu lainnya, dalam artian bahwa ilmu hukum itu memiliki ciri karakter yang khas yan di refleksikan dalam sifat normatifnya. ${ }^{4}$ Dalam penelitian yuridis normatif ini menggunakan pendekatan perundangundangan (Statute Approach). Pendekatan perundang-undangan yaitu pendekatan yang dilakukan dengan menelaah semua undangundang dan regulasi yang bersangkutan dengan permasalahan (isu hukum) yang ditangani. ${ }^{5}$

\section{Bahan Hukum Primer}

Bahan hukum primer pada penelitian ini adalah bahan hukum yang menjadi fokus dalam penelitian skripsi ini, seperti:

a. Undang-Undang Dasar Negara Republik Indonesia Tahun 1945

b. Undang-Undang nomor 39 tahun 1999 tentang hak asasi manusia

c. Undang-Undang nomor 7 tahun 2017 tentang pemilihan umum.

d. Undang-undang nomor 23 tahun 2014 tentang pemilihan daerah

e. Undang-undang Nomor 6 Tahun 2020 Tentang Penetapan Perpu Nomor 2 Tahun

3Peter Mahmud Marzuki, "Penelitian Hukum", Jakarta: Kencana Prenada Media Group, 2010, hlm. 35

4Johnny Ibrahim, Teori Dan Metodoloi Penelitian Hukum Normatif Bayu Media Publishing, hlm 12

5 Peter Mahmud Marzuki, Penelitian Hukum, (Jakarta: Kencana Prenada Media Grup 2005), hlm. 94. 
2020 Tentang Pilkada 2020 di Masa Pandemi Covid 19.

f. Undang-undang No 23 Tahun 1959 tentang Keadaan Bahaya

g. Kepres Nmor 12 Tahun 2020 Tentang Penetapan Bencana Non Alam Penyebaran Virus Corona Desease 2019.

h. PKPU Nomor 13 Tahun 2020 Tentang Perubahan Kedua Atas Peraturan Komisi Penilihan Umum Nomor 6 Tahun 2020 Tentang Pelaksanaan Pemilihan Gubernur dan Wakil Gubernur, Bupati dan Wakil Bupati, dan/Atau Wali Kota dan Wakil Wali Kota Serentak Lanjutan dalam Kondisi Bencana Non Alam Corona Virus Disease 2019 (Covid 19)

2. Bahan Hukum Sekunder

Bahan hukum sekunder adalah bahan hukum untuk pengkayaan dan penguatan bahan hukum primer. Bahan hukum sekunder yang dimaksud, meliputi:

a. Karya ilmiah sarjana dan hasil penelitian

b. Buku-buku

c. Artikel atau jurnal

3. Bahan Hukum Tersier

Bahan hukum tersier yaitu bahan hukum yang mendukung bahan hukum primer dan bahan hukum sekunder dengan memberikan pemahaman dan pengertian atas bahan hukum lainnya. Bahan hukum tersier, diantaranya:

a. Media internet

b. Kamus hukum.

\section{METODE PENELITIAN}

Metode penelitian yang digunakan hukum normatif, yaitu suatu proses untuk menemukan aturan hukum, prinsip-prinsip hukum, maupun doktrin-doktrin hukum guna menjawab isu hukum yang dihadapi. ${ }^{6}$ Ilmu Hukum berbeda dengan ilmu lainnya, dalam artian bahwa ilmu hukum itu memiliki ciri karakter yang khas yan di refleksikan dalam sifat normatifnya. ${ }^{7}$ Dalam penelitian yuridis normatif ini menggunakan pendekatan perundangundangan (Statute Approach). Pendekatan perundang-undangan yaitu pendekatan yang dilakukan dengan menelaah semua undangundang dan regulasi yang bersangkutan dengan permasalahan (isu hukum) yang ditangani. ${ }^{8}$

4. Bahan Hukum Primer

Bahan hukum primer pada penelitian ini adalah bahan hukum yang menjadi fokus dalam penelitian skripsi ini, seperti:

i. Undang-Undang Dasar Negara Republik Indonesia Tahun 1945

j. Undang-Undang nomor 39 tahun 1999 tentang hak asasi manusia

k. Undang-Undang nomor 7 tahun 2017 tentang pemilihan umum.

1. Undang-undang nomor 23 tahun 2014 tentang pemilihan daerah

6Peter Mahmud Marzuki, "Penelitian Hukum", Jakarta: Kencana Prenada Media Group, 2010, hlm. 35

7Johnny Ibrahim, Teori Dan Metodoloi Penelitian Hukum Normatif Bayu Media Publishing, hlm 12

8 Peter Mahmud Marzuki, Penelitian Hukum, (Jakarta: Kencana Prenada Media Grup 2005), hlm. 94. 
m. Undang-undang Nomor 6 Tahun 2020 Tentang Penetapan Perpu Nomor 2 Tahun 2020 Tentang Pilkada 2020 di Masa Pandemi Covid 19.

n. Undang-undang No 23 Tahun 1959 tentang Keadaan Bahaya

o. Kepres Nmor 12 Tahun 2020 Tentang Penetapan Bencana Non Alam Penyebaran Virus Corona Desease 2019.

p. PKPU Nomor 13 Tahun 2020 Tentang Perubahan Kedua Atas Peraturan Komisi Penilihan Umum Nomor 6 Tahun 2020 Tentang Pelaksanaan Pemilihan Gubernur dan Wakil Gubernur, Bupati dan Wakil Bupati, dan/Atau Wali Kota dan Wakil Wali Kota Serentak Lanjutan dalam Kondisi Bencana Non Alam Corona Virus Disease 2019 (Covid 19)

5. Bahan Hukum Sekunder

Bahan hukum sekunder adalah bahan hukum untuk pengkayaan dan penguatan bahan hukum primer. Bahan hukum sekunder yang dimaksud, meliputi:

d. Karya ilmiah sarjana dan hasil penelitian

e. Buku-buku

f. Artikel atau jurnal

6. Bahan Hukum Tersier

Bahan hukum tersier yaitu bahan hukum yang mendukung bahan hukum primer dan bahan hukum sekunder dengan memberikan pemahaman dan pengertian atas bahan hukum lainnya. Bahan hukum tersier, diantaranya:

c. Media internet

d. Kamus hukum.

\section{HASIL DAN PEMBAHSAN}

\section{Pengertian Pemilihan Umum}

Pemilu merupakan salah satu konsep demokrasi yang dipilih untuk memilih pemimpin dalam sebuah Negara tentunya hal ini sangat berpengaruh terhadap masa depan indonesia, hal tersebut sudah memiliki payung hukum tetap, sehingga peran pemilu sangat urjen, pesta demokrasi tersebut untuk memilih pemimpin yang akan menjadi tolak ukur untuk kesejahteraan masyarakat, agenda pemilu dilaksanakan lima tahun sekali, biasanya masyarakat antusias untuk memilih para paslon.

Sesuai dengan ketentuan Undang-undang yang berlaku yaitu Undang-undang Nomor 8 Tahun 2012 Tentang Pemilihan Umum Anggota Dewan Perwakilan Rakyat, Dewan Perwakilan Daerah dan Dewan Perwakilan Rakyat Daerah, pengertian pemilihan umum diuraikan secara detail. Pemilu adalah sarana pelaksanaan kedaulatan rakyat yang dilaksanakan secara langsung, umum, bebas, rahasia, jujur, dan adil dalam Negara Kesatuan Indonesia berdasarkan Pancasila dan Undangundang Dasar Negara Republik Indonesia 1945.

Menurut Harris G. Warren, pemilu adalah "kesempatan bagi warga negara untuk memilih pejabat pemerintah dan memilih apa yang harus dilakukan pemerintah." Dan dengan keputusan ini, warga menentukan apa yang sebenarnya mereka inginkan. Sedangkan menurut A. Sudiharto, pemilu merupakan sarana penting demokrasi dan wujud nyata 
partisipasi rakyat dalam kehidupan bernegara.. 9

\section{Pengertian Staatsnoodrech}

Menurut Kabul Arifin dkk, istilah staatsnoodrecht dalam pengertian subjektif tidak tertulis atau yang biasa disebut dengan staatenoodrecht harus diterjemahkan ke dalam bahasa Indonesia dengan istilah hak darurat negara atau hukum tata negara darurat subjektif. Istilah staatsnoodrecht dalam pengertian objektif tertulis sebagai lawan dari staatsnoodrecht subjektif, harus diterjemahkan ke dalam hukum darurat (Tatanegara), sedangkan istilah hukum tata negara darurat digunakan sebagai terjemahan dari istilah tertulis noodstaatsrecht. Dengan kata lain, terdapat persamaan antara pengertian staatsnoodrecht dalam arti objektif dengan pengertian noodstaatsrecht yang tertulis, yang keduanya dapat diterjemahkan dengan katakata hukum tata negara darurat atau kita dapat menyebutnya hukum tata negara darurat. Dengan demikian, sebagaimana dikemukakan oleh Kabul Arifin dkk, dunia akademik cukup menggunakan dua istilah yang dapat dengan mudah dibedakan satu sama lain, yaitu:

a. Hukum tatanegara darurat subjektif sebagai terjemahan dari istilah Staatsnoodrecht dalam arti subjektif.

9 Ramlan Surbakti Memahami Ilmu Politik.(Jakarta : PT Grasindo 1992, Hlm 15 b. Hukum tata neagara darurat saja sebagai terjemahan dari perkataan Staatsnoodrecht dalam arti objektif. ${ }^{10}$

Di negara-negara seperti Indonesia, potensi kerawanan sangat besar, baik yang disebabkan oleh fenomena alam maupun oleh aktivitas manusia. Masyarakat Indonesia sangat beragam, baik dari segi keyakinan agama, suku dan tradisi budaya, maupun dari segi tingkat pendidikan dan kesejahteraan secara umum. Jumlah penduduk Indonesia juga sangat besar, yaitu beberapa negara dengan jumlah penduduk terbesar keempat di dunia.

\section{Kategori Keadaan Darurat Di Masa}

\section{Covid 19}

Berdasarkan pengertian darurat berikut kriterianya yang sudah saya sampaikan, pandemi Covid-19 memenuhi semua kriteria tersebut, sehingga sebenarnya sudah cukup jelas bahwa Indonesia saat ini berada dalam situasi darurat. Hanya saja dalam konstitusi diatur bahwa penilaian apakah negara itu berada dalam situasi darurat atau tidak, hal itu menjadi kewenangan istimewa (hak prerogatif) Presiden. Kreteria covid pun sudh termasuk pada darurat kesehatan,

Maka dari itu pemilukada yang terlaksana di tengah benacana non alam itu sudah melanggar aturan yang berlaku, sehingga harus ada terobosan hukum, baik berbentuk Perpu maupun Perpres, Inpres untuk menentukan Covid-19 itu masuk dalam

10 Jimly Asshiddiqie "Hukum Tata Negara Darurat”. 2007 jakarta PT Raja Grafindo Persada Hal 25 
kategori bencana non alam, dan ketika masuk dalam konteks pemilukada maka wajib hukumnya di tunda jika covid-19 termasuk bencana kesehatan nasional, dan penundaaan tersebut harus tercantu dalam PKPU, yang mana peundaan tersebut harus melihat Negara kembali normal,. Sehingga dalam konteks penundaan pemilu tidak cacat hukum. namun sebaliknya jika pemilu tetap terlaksana di tengah bencana kesehatan nasional, maka itu sudah melanggar aturan yang sudah berlaku, yang tertuang dalam "pasal 12 dan pasal 22 UUD 1945”.

\section{Korelasi Konsep Negara Dalam}

Keadaan Darurat terhadap kondisi pada masa pandemi Covid 19

Menurut Jimly Assyiddiqy, ketentuan status bahaya yang tertulis dalam pasal 12 secara tegas menekankan sifat bahaya yang akan segera terjadi, sedangkan urgensi imperatif pada pasal 22 lebih menekankan pada aspek kebutuhan hukum yang mendesak atau mendesak terkait dengan masalah keterbatasan waktu. Untuk satu hal, ada elemen yang masuk akal. Kebutuhan, tetapi di sisi lain terhadap batasan waktu yang terbatas. Oleh karena itu, ada tiga elemen penting yang secara bersama-sama membentuk konsep situasi berbahaya yang menciptakan urgensi imperatif, yaitu:

a. Unsur ancaman yang

membahayakan (danger ous

threat) b. Unsur kebutuhan yang

menharuskan(reasonable

necessty)

c. Unsur keterbatasan waktu

(limited time)

Tiga unsur diatas meruapakn salah satu pedoman untuk menentukan sebuah negara apakah termasuk Staadnoodrecht ancaman yang membahayakan atau bencana alam atau non alam, namun salah satu tiga unsur itu masuk maka dalam konteks bernegara wajib mematuhi peraturan peraturan yang berlaku tentang keadaruratan nasional. ${ }^{11}$

keadaan darurat dibedakan menurut tingkatan bahayanya, yakni darurat sipil, darurat militer, dan darurat perang. UU No. 23 Tahun 1959 menggunakan tiga kriteria untuk menentukan suatu keadaan darurat. Pertama, keamanan dan ketertiban hukum di seluruh atau sebagian wilayah Indonesia terancam oleh pemberontakan, kerusuhan atau bencana alam sehingga tidak dapat diatasi oleh alat-alat perlengkapan secara biasa. Kedua, timbul perang atau bahaya perang atau dikhawatirkan perkosaan wilayah Indonesia dengan cara apapun. Ketiga, hidup negara berada dalam keadaan bahaya atau dari keadaan-keadaan khusus ternyata ada atau doikhawatirkan ada gejala-gejala yang dapat membahayakan hidup negara.

Menurut Prof. Herman, unsur-unsur dalam Hukum Tata Negara darurat adalah:

11 Jimly Asshiddiqie Op cit hal 207- 
a. adanya bahaya negara yang patut dihadapi dengan upaya luar biasa;

b. upaya biasa, pranata yang umum dan lazim tidak memadai untuk digunakan menanggapi dan menanggulangi bahaya yang ada;

c. kewenangan luar biasa yang diberikan dengan hukum kepada pemerintah negara untuk secepatnya mengakhiri bahaya darurat tersebut, kembali ke dalam kehidupan normal;

d. wewenang luar biasa dan hokum tata negara darurat berlaku untuk sementara waktu saja sampai keadaan darurat itu dipandang tidak membahayakan lagi.

Menurut Sumantri, hukum darurat biasanya tertuang dalam hukum darurat. Undang-undang darurat dibuat oleh Pemerintah dengan ketentuan sebagai berikut: keadaan darurat; keamanan membahayakan dan mengancam tegaknya negara; untuk mengatasi keadaan dan kesulitan yang timbul dari keadaan bahaya; tidak ada kesempatan untuk berbicara dengan parlemen (dan Senat); dan hukum hanya berlaku selama ada bahaya. Dan hal tersebut yang menentukan yaitu presiden, Jika syarat tersebut tidak terpenuhi, kata dia, undang-undang yang dibuat oleh pemerintah melanggar sistem demokrasi, melanggar prinsip kerakyatan dan biasanya melanggar hak asasi manusia. ${ }^{12}$

Prof. Purnomo Yusgiantoro Ancaman itu sendiri adalah segala kegiatan yang berasal dari dalam dan luar negeri yang membahayakan Negara Kesatuan Republik Indonesia dan keamanan bangsa, atau merupakan penghambat dan penghambat kepentingan nasional, Ancaman merupakan faktor utama mendasari bentuk nyata dan potensial dari pencegahan. (belum nyata), beliau juga menjelaskan cara menghadapi ancaman yaitu melalui deterrence yaitu personifikasi upaya pertahanan dan keamanan negara dari seluruh kekuatan nasional yang bekerja secara psikologis untuk mencegah dan melakukan ancaman baik dari luar negeri maupun dari luar negeri. luar negeri di dalam negeri. perbatasan nasional. Setiap warga negara berkewajiban menghadapi ancaman nyata dan potensial untuk melindungi kedaulatan, keutuhan dan keamanan bangsa. ${ }^{13}$

Sejak disahkan dan disahkannya "UUD 1945” pada tanggal 18 Agustus 1945, peraturan baru tentang situasi berbahaya sebagaimana dimaksud dalam "pasal 12 UUD 1945" telah ditetapkan dalam beberapa undang-undang. Undang-undang terakhir yang mengaturnya adalah "Undang-undang Nomor 2 Tahun 1959" yang diundangkan pada tanggal 16 Desember 1959. Dengan

12 M.Yasin Staadnoodrecht dalam pandanga tiga tokoh 23 april 2019 Hukum Online.com

${ }^{13}$ https//www.itb.ac,id/berita/detail/5 7328/belajar memahami teori ancaman. 
berlakunya "undang-undang” ini, undangundang sebelumnya, "Undang-Undang Nomor 74 Tahun 1957”, dinyatakan tidak berlaku.

Konsep darurat sipil adalah keadaan darurat di mana tingkat bahaya dianggap paling rendah dari segi risiko terendah. Karena tingkat bahaya ini, tidak ada operasi kontra yang diperlukan di bawah kepemimpinan komando militer, bahkan jika anggota tentara atau angkatan bersenjata harus menghadapi situasi kegentingan yang memaksa, kehadiran mereka hanya bersifat solidaritas.Operasi untuk membalikkan keadaan tetap berada di bawah kendali dan tanggung jawab pejabat sipil. $^{14}$

Keadaan darurat sipil itu sendiri dapat timbul karena berbagai sebab atau faktor, baik yang bersifat alam, manusia dan/atau hewan, sebab-sebab alam adalah sebab-sebab yang timbul sebagai akibat dari bencana alam, baik yang berasal dari usus darat, laut maupun udara. . Penyebab gila adalah penyebab yang dapat ditelusuri kembali ke aktivitas manusia, sedangkan penyebab hewan adalah bencana yang disebabkan oleh hewan yang menyebabkan wabah penyakit meluas.

Ditambah dengan momentum Pilkada Serentak 2020, Indonesia mencapai angka kematian harian tertinggi. Menurut data Pokja Covid19, hingga saat ini 171 orang meninggal dunia. Pada 27 dan 29 November 2020, sebanyak 169 orang meninggal, jumlah tertinggi hingga saat ini. Sementara itu, total

14 op cit hal 306-307
18.171 orang meninggal dunia akibat Covid19 di Indonesia. Selengkapnya di artikel "Update Mahkota Indonesia Selama Pilkada 2020: Angka Kematian Tertinggi". ${ }^{15}$

Dengan data angka kematian yang terjadi pada saat pemilu pada masa pandemi di tengah pandemi, maka unsur dan konsep ancaman bahaya (dangerous threat) secara tegas tertuang dalam peraturan perundang-undangan darurat yang berlaku, konteksnya tidak tepat untuk dipertahankan. pemilihan kepala daerah di tengah konflik. Pandemi dan Keadaan Darurat Kesehatan Nasional. Agar hal-hal yang terjadi sebagai petunjuk di kemudian hari, sedangkan masyarakat harus dilindungi.

\section{Pemilihan Umum di Indonesia Dalam Masa Darurat}

Pemilihan Umum kepala daerah tahun ini sangat berbeda dengan pemilihan kepala daerah sebelumnya, karena ini merupakan pemilihan kepala daerah yang pertama di tengah pandemi Covid19. Terkait Pilkada Serentak tahun 2020 yang juga akan bertepatan dengan terjadinya pandemi Covid19, pemerintah juga sedang memikirkan dan Mengantisipasi Pilkada ini tetap harus dilaksanakan, Pilkada ini sebelumnya ditunda, dimana sebelumnya Pilkada ini direncanakan pada 23 September 2020 kemudian harus ditunda hingga 9 Desember 2020. Sesuai dengan "keputusan bersama antara KPU, Bawaslu , Pemerintah dan DPR," serta

15 https://tirto.id/update-coronaindonesia-saat-pilkada-2020-angkakematian tertinggi-f $7 \mathrm{Xh}$ 
terbitnya Undang-Undang Nomor 6 Tahun 2020 tentang Penetapan Peraturan Pemerintah Pengganti Undang-Undang Nomor 2 Tahun 2020 tentang Perubahan Ketiga Atas UndangUndang Nomor 1 Tahun 2014 tentang Pemilihan Gubernur, Bupati dan Walikota Menjadi Hukum.

Terkait penyelenggaraan pemilu parlemen di berbagai negara,dalam kasus covid-19 ini, maka dalam pelaksanaan pemilu 55 negara sudah menyatakan sah menunda terkait dengan agenda emilihan umu tersebut, tetapi sebaliknya ada 21 negara yang masih belum menunda pemilu umumnya 9 diantaranya yaitu korea selatan, yang di selenggarakan pada tanggal 15 april 2020, sdangkan indonesia sendiri ingin melkasnakan pada tanggal 9 desember 2020, namun hal tersebut sangat dkowatirkan karena yang di takutkan aka nada klaster baru yaitu klaster penyebaran covid 19 karena diakui atau tidak diakui yang namanya pemilu itu pasti terjadi kerumunan. ${ }^{16}$

\section{Konstitusinalisme Sebagai Dasar}

Penundaan Pemilihan Umum

Berbicara tentang keadaan darurat dapat dikonseptualisasikan dalam 2 (dua) kategori, yaitu keadaan berbahaya dan hal-hal yang mendesak. Sekalipun kedua kategori tersebut memiliki arti yang sama, yaitu darurat (abnormal), tetapi secara konseptual dari segi hukum tata negara, keduanya pada dasarnya berbeda. Hal ini dapat dilihat dalam rumusan konstitusi itu sendiri, dimana keadaan bahaya

\footnotetext{
16 Aprista Ristyawati Jurnal Crepido, Volume 02, Nomor 02, November 2020, hal 85
}

diatur secara khusus dalam "pasal 12 UUD NRI 1945", sedangkan kategori "hal-hal yang mendesak" diatur dalam pasal 22 UUD NRI 1945 Konstitusi. $^{17}$

Penggunaan kedua pasal tersebut memiliki perbedaan yaitu pasal 12 UUD NRI 1945 lebih menitikberatkan pada subjektivitas presiden sebagai kepala negara untuk melindungi bangsa dan negara dari campur tangan pihak luar (faktor eksternal), sedangkan penggunaan pasal 22.1945 konstitusi berada dalam wilayah regulasi, yaitu berkenaan dengan subjektivitas. Kewenangan Presiden untuk menetapkan Perppu tersebut kemudian diobjektifkan oleh FREP pada sidang paripurna berikutnya. ${ }^{18}$

\section{Konsep Pemilukada yag terlaksana dalam Masa Pandemi Covid 19}

Pemilu disaat masa darurat menarik untuk dikaji secara "perundang-undangan" tentang kedaruratan karena ini merupakan kali pertama pemilihan kepala daerah berlangsung di tengah pandemi Covid19. Terkait Pilkada Serentak tahun 2020 yang juga bertepatan dengan terjadinya pandemi Covid19, pemerintah telah berpikir cepat dan matang serta mengantisipasi agar Pilkada ini belum terlaksana; Pemilihan ini juga ditunda sebelum

17 Madaskolay Viktoris Dahoklory "Penanggulangan Keadaan Darurat Ancaman Covid-19 dalam Sudut Pandang Tata Negara” Jurnal Keamanan Nasional Volume VI, No. 2, November 2020

18Muhammad Syarif Nuh. Hakekat Keadaan Darurat (State of Emergency) sebagai Dasar Pembentukan Peraturan Pemerintah Pengganti Undang-Undang. Jurnal Hukum. No. 2, Vol. 18 (2011): 233 
pemilihan kepala daerah. yang dijadwalkan pada 23 September 2020, terpaksa ditunda hingga 9 Desember 2020. Sesuai keputusan bersama antara KPU, Bawaslu, pemerintah dan DPR, serta berlakunya UU Nomor 6 Tahun 2020 tentang pembentukan peraturan pemerintah pengganti UU No. 2 Tahun 2020 untuk tiga reformasi legislatif. Nomor 1 dari 2014 "UU pemilihan gubernur, bupati, dan walikota disahkan. ${ }^{19}$

Momentum terkait dengan pelaksanaan pemilukada tidak terlepas pada ketentauanketenutuan yang sudah di tentukan oleh pihak penyelenggara yaitu, pelaksanaan pilkada serentak kualitas hasil pemilu akan menjadi sorotan, karena pasalnya, dengan menggunakan konsep prokes di tengah pandemi semakin merambah ke semua daerah, tentunya akan sulit dilaksanakan pemilu di tahun 2020 ini, konsekuensi yangharus diambil ketika memaksakan pemilukada di laksanakan di tengah pandemic yaitu, kan bertambanhy klaster baru di tengah merambahnya covid 19 .

Dalam pelaksaan pemilukada di tengah pandemic, yaitu tantangan yang paling terbesar adalah mengenai di sektor keuangan, hal tersebut akan timpang sebelah jika pemilukada dilaksanakan di tengah krisis ekonomi, dimna di satu sisi pemerintah harus membagikan anggaran APBD baik dari sektor penanggulangan bencana non alam maupun sebaliknya, bahwa pelaksanaan pemilukada di

19 Sonia desi lestari "Pelaksanaan pemilihan kepala daerah di masa pandemi", 23-september 2020 tengah pandemi akan mengeluarkan belanja Negara sangatlah tinggi, namun kendatipun tetap akan terlaksna pemilukada di tengah pandemi covid 19. ${ }^{20}$

\section{KonstitusionalNegara}

Terhadap

Pemilihan Umum yang dilaksanakan di tengah keadaan Negara dalam kondisi

Darurat

Pemilu yang dilakukan pada masa darurat adalah batal demi hukum, karena konsep staadnoodrech yang sebenarnya dalam studi akademis telah disusun sedemikian rupa sehingga, tentu saja, merupakan faktor penting yang harus diperhatikan oleh pemerintah. Peraturan perundang-undangan yang berlaku atau dapat diberlakukan dalam keadaan darurat antara lain peraturan perundang-undangan yang menjadi acuan dalam mengeluarkan keadaan darurat, serta peraturan perundangundangan yang dikeluarkan dalam keadaan darurat. Dalam konteks Indonesia, bentuk kelompok pertama peraturan perundangundangan dapat berupa;

a. UUD NRI1945

b. Undang-undang tentang keadaan bahaya yang secara khusus harus lebih dulu di susun untuk mengatur keadaan darurat di maksud sesuai amanat pasal 12 UUD NRI 1945

c. Keputusan presiden atau peraturan presiden yang ditetapkan dalam rangka pemberlakuan keadaan darurat atau keadaan bahaya dimaksud

$$
20 \text { op cit }
$$


d. Peraturan-peraturan perundang-undangan lain dari masa sebelumnya yang dalam keadaan bahaya dianggap masih berlaku dan tetap di perlukan. ${ }^{21}$

Dalam ketetapan kontitusi tentang keadruratan maka hal tersebut hal tercantum di dalam Undang-undang Dasar 1945:. ${ }^{22}$

a. Bentuk hukum keadaan darurat adalah pernyataan keadaan bahaya harus dituangkan dalam bentuk undangundang. Berlakunya suatu keadaan darurat iitu tidak mungkin dituangkan dalam bentuk undang undang yang harus lebih dahulu mendapat persetujuan DPR. Oleh sebab itu, ada tiga (3) alternative yang mungkin dipilih yaitu, pernyataan dituangkan dalam bentuk Peraturan Presiden, pernyataan dituangkan dalam bentuk Perpu, dan pernyataan dituangkan dalam bentuk Keputusan Presiden.

b. Bentuk tindakan pernyataan darurat merupakan jenis dan corak keadaan darurat yang melibatkan peran kekuasaan untuk mengatasinya, dan sebelumya perlu identifikasi mengenai bentuk tindakan kekuasaan.

Keempat perangkat standar regulasi tersebut harus menjadi pedoman atau sumber hukum bagi presiden untuk menentukan

21 Jimly asshiddiqie "hukum tata negara Darurat 2007 jakarta raja grafindo persada hal, 77

22 Tinjauan Yuridis Terhadap Penetapan Keadaan Darurat Berdasarkan Undangundang Dasar Negara Republik Indonesia Tahun 1945 penerapan keadaan bahaya atau darurat. Bahkan setelah keadaan demikian telah resmi diberlakukan, penguasa keadaan darurat masih mempunyai kewenangan untuk mengeluarkan peraturan-peraturan dalam menjalankan kekuasaannya. Bentuk peraturan perundangundangan yang dapat dibentuk pada masa darurat adalah sebagai berikut;

a. Peraturan pemerintah pengganti Undangundang

b. Peraturan presiden

c. Intruksi presiden ${ }^{23}$

Hukum darurat ditulis dan diterapkan untuk "mengatasi krisis", atau setidaknya diterapkan hanya pada saat krisis. Dengan ciriciri tersebut, tampak bahwa hukum yang masih diperbolehkan diterapkan sejak masa penjajahan Belanda bukanlah hukum darurat, masih dianggap perlu untuk diterapkan dan belum dihapuskan karena belum ada penggantinya, karakteristik mengatasi krisis sama sekali dalam hak itu.

\section{Dasar Hukum Penundaan Pemilu Dalam Masa Darurat Secara} Perundang-undangan yang berlaku

Proses penundaan pemilu harus benarbenar di prioritaskan oleh pemerintah, dalam keputusan yang harus diambil yaitu menunda pemilu kada yang tepat sasaran, sehingga kemanan dan kenyamanan masyarakatlah yang menjadi priritas bukan lagi bicara mengenai kepentingan politik pragtis, dengan benyak 23 Opcit hal 77 
alasan yang tidak relevan untuk terlaksananya pemilukada di tengah covid 19 angka kematian meningkat, maka secara keadaan kegeningan yang memksakan untuk ditunda maka wajib secara hukum pemerintah harus mengambil sikap terkait dengan penundaan pemilu, hal tersebut yang menjadi dasar yaitu berbicara tentang keselamatan seluruh rakyat baik penyelenggara maupun hak pemilih, Perppu No. 23 Tahun 1959 tentang keadaan Bahaya menjelaskan konsep keadaan berbahaya dalam tiga kategori, yaitu pertama darurat sipil, yang meliputi kerusuhan, perang saudara, dan bencana alam.

Kedua, darurat militer menyiratkan pemberontakan (bersenjata) di dalam negeri. Ketiga, keadaan darurat militer mencakup situasi perang, baik di dalam negeri maupun di luar negeri. Sejarah telah mencatat bahwa keadaan "darurat sipil" dideklarasikan di provinsi Maluku pada tahun 2000-2002 dan di provinsi Aceh pada tahun 2002, sedangkan keadaan "darurat militer" juga dideklarasikan di provinsi Aceh pada tahun 2003 dan di Timor Timur diproklamasikan pada tahun 1999. Tidak pernah secara hukum ditetapkan "darurat perang" di wilayah Republik Indonesia, situasi perang de facto telah muncul di wilayah Republik Indonesia. Selanjutnya, keadaan darurat hukum yang terakhir adalah "darurat kesehatan masyarakat" di seluruh wilayah Negara Kesatuan Republik Indonesia.

Pada era 1955, terjadi penundaan pemilu di Indonesia karena perbedaan pandangan tentang dasar hukum yang digunakan untuk menyelenggarakan pemilu, menjadikan undang-undang pemilu sebagai pelindung hukum dalam penyelenggaraan pemilu pada saat itu, memungkinkan partai-partai untuk mengadakan pemilu. pemilihan parlemen ditunda. , perbedaan pendapat itu juga mempengaruhi tidak aktifnya DPR saat itu. Dalam arti peristiwa tersebut dapat digolongkan sebagai darurat konstitusi, karena pada waktu itu masih terjadi peralihan kekuasaan di bawah pimpinan penjajah pada waktu itu.

Pemilihan Umum yang dijanjikan itu kembali ditunda ketika pemerintah menerima amanat Presiden Soekarno pada pembukaan Kongres ke-10 PNI pada tanggal 20 di Purwokerto. Bahkan seperti yang tertuang dalam pidato pertanggungjawaban presiden yang kita kenal sebagai Nawaksara, Soekarno menyampaikan pada th, tapi seruan presiden itu ditenggelamkan dalam hiruk pikuk demonstrasi dan sidang khusus MPRS. Tidak lagi di pihak pemimpin revolusioner yang besar,pemilihan diadakan hanya setelah presiden digulingkan pada tahun 1967, bahkan sampai kematiannya pada tahun 1970 .

Jika melihat keadaan genting hal tersebut, maka sewajarnya pemerintah atau pmangku kekuasaan yaitu presiden yang harus membuat tidakan, baik tindakan itu bebentuk hukum yang kita kenal dengan perpu atau perpres atau intruksi presiden untuk tidak melaksanakan pemilu yang dilaksnakan di tahun 2020 yang kemudian dimana pada tahun tersebut masighgenting-gentingnya penyebaran virus Covid-19 sedangkan dalam "Pasal Pasal 22 Undang-Undang Dasar Negara Republik 
Indonesia" bahwa "Dalam hal ihwal kegentingan yang memaksa, Presiden berhak menetapkan peraturan pemerintah sebagai penggati Undang-Undang. "24

\section{Ketentuan Hukum Pelaksanaan}

Pemilukada di Masa Covid 19

KPU-RI Telah menetapkan bahwasanya pemilihan Serentak akan dilaksanakan pada 9 Desambar 2020 Mendatang dengan Ketentuan-Ketentuan yang berlaku sesuai Peraturan yang diterbitkan oleh KPURI Melalui PKPU No 6 Tahun 2020 Tentang Pelaksanaan Pemilihan Gubernur dan Wakil Gubernur, Bupati dan Wakil Bupati, Walikota dan Wakil Walikota Serentak Lanjutan dalam Kondisi Bencana Non Alam Corona virus diserase 2019. Jika diperhatikan sekilas Pandemi Covid-19 di Indonesia Berdasarkan Data yang diperoleh Peneliti Kian Meningkat Setiap harinya bahkan Jauh dari awal terjadinya Pandemi yakni 357.762 kasus yang terkonfirmasi dengan 281.592 dengan 12.431 kasus meninggal.

Dengan demikian maka akan Sangat di perlunya dipertimbangkan kembali opsi penundaan kembali pemilihan umum serentak tersebut hingga keadaan benar-benar kondusif dan memungkinkan untuk melakukan perkumpulan beramai-Ramai. Apa lagi penundaan tersebut telah didukung dengan Perpu No 2 Tahun 2020 yang belakangan menjadi UndangUndang No 6 Tahun 2020 yang menyatakan pada "pasal 120 ayat 1"

24 Buletin Hukum dan Keadilan, Vol. 4, No. 1 (2020) hal 120 ISSN 23384638 yang "menyatakan bahwa Dalam hal pada sebagian wilayah Pemilihan, seluruh wilayah Pemilihan, sebagian besar daerah, atau seluruh daerah terjadi kerusuhan, gangguan keamanan, bencana alam, bencana nonalam, atau gangguan lainnya yang mengakibatkan sebagian tahapan penyelenggaraan Pemilihan atau Pemilihan serentak tidak dapat dilaksanakan, dilakukan Pemilihan lanjutan atau Pemilihan serentak lanjutan”. Begitupun pada ayat 2 yang menyatakan bahwa "Pelaksanaan Pemilihan lanjutan atau Pemilihan serentak lanjutan sebagaimana dimaksud" "pada ayat 1 dimulai dari tahapan penyelenggaraan Pemilihan atau pemilihan serentak yang terhenti”. ${ }^{25}$

\section{KESIMPULAN}

Hakekat makna dari pada demokrasi beberapa para ahli telah memberikan pendapatnya terkait defini demokrasi yang sebenarnya, diantranya ada pendapatnya dari hendry B. mayo, dan W.A bonger serta pendapatnya jamaluddun. Yang dapat diambil benang merah bahwa hakekat makna demokrasi itu adalah didalam pengambulan kebijakan umum ditentukan secara langsung oleh rakyat baik laki-laki ataupun perempuan tanmpa membedakan trans jender atau perwakilan yang diawasi secara efektif oleh

25 Undang-Undang No 6 Tahun 2020 Tentang Perubahan Ketiga Atas Undang-Undang Nomor 1 Tahun 2015 Tentang Penetapan Peraturan Pemerintah Pengganti UndangUndang Nomor I Tahun 2014 Tentang pemilihan Gubernur,Bupati dan Walikota menjadi undang-undang 
rakyat dengan tetap berdasarkan atas prinsip kesamaan politik serta diselemnggrakan dalam suatu terjaminya kebebasan politik. Oleh karenya maka jika disingkronkan dengan konsep pemilihan keterwakilan perempuan dalam pengisian anggota BP, yang diatur didalam permendagri nomor 110 tahun 2016 tepatnya dipasal 8 ayat (3) hal itu justru tidak mencerminkan makna hakekat yang sesungguhya dari demokrasi.

Inkonsistensi terjadi didalam permendagri no 110/2016 tentang BPD tepatnya di pasal 8 ayat (3) disana tidak mencerminkan sitem demokratis dalam pemilihan keanggotaan BPD dari keterwakilan perempuan. Ditinjau dari aspek sistem hukum yakni khirarki peraturan perundang-undngan maka seharus nya pasal 8 ayat (3) permendagri no 110/2016 tidak boleh bertentangan dengan peraturan diatasnya yakni UU no 6/2014 dan PP no 43/2014. Pasalnya didalam peraturan diatanya menegaskan bahwa sistem pemilihan dari pada keanggotaan BPD itu dilakukan secara demokratis. Didalam konteks hukum islam perempuan diperbolehkan perperan dibidang publik tidak nya dibidang domestik, hak ini bersifat derogable rights (yang dapat dikurangi) yang termasuk jenis hak partikularisme relatif. Indonesia dikenal negara hukum maka harus menjadikan demokrasi sebagai suatu sistem didalam pemerintahanya sebab kedua konsep ini (demokrasi dan negara hukum) tidak bisa dipisahkan. dikarenakan jika satu suatu negara diselenggarakan dari, oleh dan untuk rakyat, maka untuk menghindari Hak rakyat dari kesewenang-wenangan dan untuk melaksanakan kehendak rakyat bagi pemegang kekuasaan negara haruslah segala tindakannya dibatasi atau dikontrol oleh hukum hal ini sejalan dengan pendapatnya jimly Asshiddiqie dan diperkuat oleh pendapatnya mahfud MD dalam bukunya.

Ditinjuau dari aspek kearifan lokal, Implikasi dari konsep dan common sense tentang pemosisian yang tidak seimbang telah menjadi kekuatan didalam pemisahan sektor kehidupan didalam sektor domestik dan sektor publik, dimana perempuan dianggap orang yang berkiprah dalam sektor domestik sementara laki-laki ditempatkan dalam sektor publik, maka sangat tidak memungkinkan jika keterwakilan perempuan dalam keanggotaan BPD pemilihanya hanya dilakuakan oleh perempuan.

\section{SARAN}

Demi tercapainya suatu sistem demokratis didalam pengisian keanggotaan BPD dari keterwakilan perempuan yang diatur didalam pasal 8 ayat (3) permendagri no 110/2016, maka sistem pemilihanya harus melibatkan peran serta dari semua masyrakat dewasa tanpa membedakan trans jender baik laki-laki ataupun perempuan, untuk turut ikut serta dalam pengambilan keputusan politik khusunya pemilihan keterwakilan perempuan dalam keanggotaan BPD, Dalam Hal ini bertujuan demi tercapainya hak-hak kedaulatan rakyat. Serta masyarakat bisa menikmati secara utuh hak kebebasan berpolitik. 
Agar tidak terjadinya inkonsistensi di pasal 8 ayat (3) peremendagri no 110/2016 dengan peraturan diatanya, maka disarankan untuk dilakukan judicial review atau diujikan kembali pasal tersebut ke mahkamah agung, dengan maksud dan tujuan untuk mengubah konsep atau mekanisme pengisian keterwakilan perempuan dalam keanggotaan BPD yang sesuai dengan sistem demokrasi yang sebenarnya, sebagaimana yang telah diperintahkan oleh peraturan diatasnya yakni UU no 6/2014 pasal 56 ayat (1) dan peraturan pelaksaanya yakni PP no 43/2014. 


\section{DAFTAR PUSTAKA}

Buku:

Jimly Asshiddiqie," Hukum Tata Negara Darurat"2007 $R \quad$ Raja Grafindo Persada, hal 205

Tomy Michael Tomy 163 Hukum Tata Negara Darurat Corona Di Indonesia volume 13 Nomor 2 Agustus 2020

Peter Mahmud Marzuki, "Penelitian Hukum", Jakarta: Kencana Prenada Media Group, 2010, hlm. 35

Johnny Ibrahim, Teori Dan Metodoloi Penelitian Hukum Normatif Bayu Media Publishing, hlm 12

Ramlan Surbakti Memahami Ilmu Politik.(Jakarta : PT Grasindo 1992,

HIm 15

Jimly Asshiddiqie "Hukum Tata Negara Darurat”. 2007 jakarta PT Raja Grafindo Persada Hal 25

Aprista Ristyawati Jurnal Crepido, Volume 02, Nomor 02, November 2020, hal 85

Madaskolay Viktoris Dahoklory "Penanggulangan Keadaan Darurat Ancaman Covid-19 dalam Sudut Pandang Tata Negara" Jurnal Keamanan Nasional Volume VI, No. 2, November 2020

Muhammad Syarif Nuh. Hakekat Keadaan Darurat (State of Emergency)
sebagai Dasar Pembentukan
Peraturan Pemerintah Pengganti
Undang-Undang. Jurnal Hukum. No. 2, Vol. 18 (2011): 233

M.Yasin Staadnoodrecht dalam pandanga tiga tokoh 23 april 2019 Hukum Online.com

Https//www.itb.ac,id/berita/detail/57328/belaj ar memahami teori ancaman.

https://tirto.id/update-corona-inindonesiasaat-pilkada-2020-angkakematian tertinggi-f7Xh

Sonia desi lestari "Pelaksanaan pemilihan kepala daerah di masa pandemi" 23september 2020

Jimly asshiddiqie "hukum tata negara Darurat 2007 jakarta raja grafindo persada hal, 77

Tinjauan Yuridis Terhadap Penetapan Keadaan Darurat Berdasarkan Undangundang Dasar Negara Republik Indonesia Tahun 1945

Undang-Undang No 6 Tahun 2020 Tentang Perubahan Ketiga Atas Undang-Undang Nomor 1 Tahun 2015 Tentang Penetapan Peraturan Pemerintah Pengganti Undang-Undang Nomor I Tahun 2014 Tentang pemilihan Gubernur,Bupati dan Walikota menjadi undang-undang

Buletin Hukum dan Keadilan, Vol. 4, No. 1 (2020) hal 120 ISSN 23384638 